\title{
Housework and Family Formation - Exploring the Relationship Between Gender Division of Housework and Having Children
}

\author{
Karina Nilsson* \\ Department of Sociology, Sociologiska institutionen, Umeå universitet, SE-901 87 UMEA
}

\begin{abstract}
Declining birth rates in Europe over the last 30 years have often been associated with changes in family structure and with increased female labour market participation. In order to understand the changes in family formation, it is important to also take family relations and gender equality within the family into consideration. This article focuses on the division of housework (as a measurement of gender equality) and its impact on childbirth in Sweden. Sweden has a relatively long history of high female labour market participation, something combined with generous parental leave and subsidised child care, should allow us to explore more fully the effects of gender relations within the household on childbearing patterns. Swedish couples were classified as traditional, intermediate and modern on the basis of the reported division of housework. While the initial analyses showed that modern i.e. more gender-equal couples, were more likely to have children, the effect of the fairer distribution of housework on having children disappeared when controlling for demographic variables such as age and the number of children already in the family. The results of this and related studies indicate that more research is needed in order to establish the impact of gender relations on childbirth.
\end{abstract}

\section{INTRODUCTION}

Lower fertility rates together with increase in divorce rates, one-person households and non-marital cohabitation have featured prominently in the discussions of changes to family forms over the last decades [1-3]. The alleged demise of the traditional family and the diverse descriptions of the "new family" have often been accompanied by expressions of hope for more gender-equal partnerships [e.g. 4-6]. Women's increased labour market participation has resulted in greater (financial) independence and undeniably accounts for some of the changes in family forms [e.g. 7]. This does not mean that gender equality has been attained on the labour market and certainly not within families. Even if paid work takes up women's days, women still have the main responsibility for caring and housework [e.g. 2, 8, 9]. Increased gender equality on the labour market has not been accompanied by a fairer sharing of housework, which suggests that an examination of gender relations within families might shed considerable light on changes in family formation.

Peter McDonald [10] argues that not only institutional changes on the labour market and within the educational system, but also changes in gender relations within the family are important when explaining decline in fertility rates. Changes in fertility rates have also often been studied in the light of female employment [e.g. 11,12]. In this article I consider other kinds of work, i.e. the division of unpaid housework, and its effect on number of children in families. The Swedish context should allow us to test the extent to which gender equality influences childbirth since Sweden is considered one of the most gender-equal countries in the world

*Address correspondence to this author at the Department of Sociology, Sociologiska institutionen, Umeå universitet, SE-901 87 UMEÅ; Tel: +46 907866311; Fax: +46 90 7866694; E-mail: Karina.Nilsson@soc.umu.se
[13] and gender equality attitudes among Swedish men and women score high in a European context [14]. In addition, Sweden's comparatively long experience of female labour market participation [15] and the accompanying normalisation of the dual-earner model [1] are coupled with relatively high and stable birth rates over the last decades [15], a relationship that has been well studied [e.g. 12, 16].

This article uses data from an eight-year longitudinal survey in order to investigate the relationship between unpaid housework and childbirth in Sweden. The main research question asked is: Does the division of housework, as a measurement of gender equality, have an impact on childbirths in Swedish families?

\section{PAID WORK AND FAMILY FORMATION}

There is no doubt that women's increased participation on the labour market has changed gender relations both at society and individual level. Paid or unpaid work outside the home is, of course, not something new for women, but female participation on the labour market in Sweden has been relatively high since the 1970s [11, 17]. And even if female labour market participation has risen elsewhere, at an average of 57\% in the European Union and 66\% in the US and Canada in 2006 [15], the corresponding Swedish figures is still well above the European average at $71 \%$.Women's increased labour market participation has resulted in what is often described as an ongoing shift from male breadwinner families to dual earner families [1, 18, 19] and Sweden, where paid labour is the norm for both men and women, can be seen as representing a completed transition. This does not, however, imply that women participate on the labour market under the same conditions as men do, since women generally earn less, have worse career opportunities and are more often found in a-typical and/or part-time employment [20, 21]. 


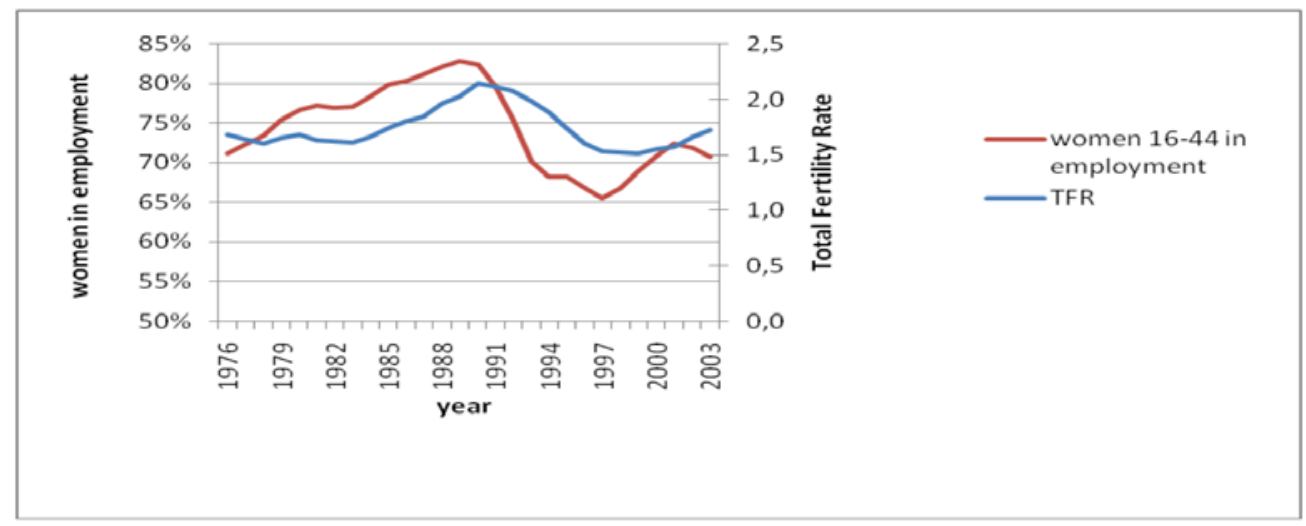

Fig. (1). Proportion of women aged 16-44 in employment and total fertility rate in Sweden between 1976-2004. (source: Statistics Sweden).

Women's changing role from homemaker to worker has affected family life in Sweden as elsewhere. At the same time as women entered the labour market on a larger scale, fertility rates in Western Europe started to drop. Negative correlations between female labour market participation and declining fertility rates have been found on data from the 1970 s, indicating that women's increased participation on the labour market brought with it a lower fertility rate in European countries [11,22]. Later data, however, reveals a positive association between fertility rates and female labour force participation. In Sweden, high labour market participation has been linked with high fertility rates over the last decades [16]. This association is shown in Fig. (1), which presents the total fertility rate and the proportion of women aged between 16 and 44 who were in employment during the 1976-2004 period. In Sweden, the proportion of women in employment within this age-span grew until 1990, when over $80 \%$ of women aged 16-44 were in some form of employment. During the early 1990s, Sweden experienced exceptionally high unemployment rates, which especially affected young adults i.e. men and women of family-forming age.

In Fig. (1), it is clearly visible that the growing proportion of women in employment during the 1980s corresponds to higher fertility rates. The fertility rates in Sweden in the late 1980s and early 1990s were above 2.0, substantially higher than the European Union (EU 15) mean of 1.51 children in 1992 [15]. The relationship between fertility rates and female employment is also apparent during the 1990s. When the proportion of women in employment starts to fall in the early 1990s, it is subsequently followed by decreased fertility rates. There is thus a strong association between female labour market participation and fertility levels on a macro level.

Microdata studies provide additional support for this association. When asked, Swedish women and men consider having stable employment as an important factor in the decisions to have children [12, 16, 23]. This is often argued to be explained by the Swedish family policy design, which strongly promotes paid employment for both men and women. Smaller segments of the support system, such as child allowance, are universal and other components, such as housing allowances are means tested [24]. The Swedish welfare system is however, largely based on attachment to the labour market, and parental leave benefits, which financially is the most important transfer scheme directly connected to having children, is based on previous earnings. For those without previous income there is a considerably lower guaranteed level of benefits. Other important family policy components are also employment related such as the parents' right to work part-time until a child is eight and the parents' paid leave for the care of sick children. Stable employment holds the key to considerable portions of the welfare system, which might explain the positive relationship between women's employment rates and fertility levels.

This relationship also applies in other Scandinavian countries, where female labour market participation has been high since the 1970s and fertility rates have declined more slowly by comparison to continental and Southern Europe. Here fertility levels have dropped dramatically over the last 20-30 years, in conjunction with women's increased participation on the labour market [25]. A number of European countries are now characterised by total fertility rates below 1.3 [15]. Country differences in family policy are often emphasized as an explanation for the disparity in fertility rates across Europe [10, 11, 22, 25, 26, 27]. It has been argued that generous welfare systems, with support for parental leave and child benefits, combined with laws that protect working parents, have kept fertility levels comparatively stable in Scandinavian countries, while the absence of child care provision and parental leave accounts for lowered fertility rates in Southern Europe.

\section{HOUSEWORK AND FAMILY FORMATION}

Sweden's comprehensive family policies aim at supporting a combination of to combine work and family life, and have mostly affected the lives of women. Women's lives have undoubtedly changed: they spend more time in paid work and the time they put into housework has decreased over the last decades [28]. The time men devote to housework has, however, not increased by the same proportion, leaving women with the main responsibility for housework and making them pull a "second shift" [29]. The gendered division of work is still apparent in dual-earner families, where women still have the main responsibility for housework, and men spending more time in paid labour $[2,9,18$, $30,31]$. This uneven distribution of housework within families has gained attention when explaining gender inequalities within society and researchers have argued that the causes of the remaining gender inequalities on the labour market 
should be sought outside the labour market, thereby pointing to the impact that the gendered division of housework has on men's and women's lives [32, 33]. The question raised in this study is whether analysing the division of housework can help us to understand family formation and especially childbirth.

The link between family formation and housework is indeed well worth exploring. Changes in family form have different implications for women and men since getting married and having children generally reinforce the gendered division of housework. The responsibility for housework are lower for men and higher for women if they are married [2, 34-37]. The gendered pattern is further accentuated in families with children, where women do even more housework $[34,38]$. Children's age is also a significant factor: in Sweden, women with children younger than 6 years have greater responsibility for housework [8]. The fact that housework is still gendered and accentuated by marriage and children, might lead us to the conclusion that in a society where women are able to make childbearing decisions, these decisions may well be influenced by the anticipated burden of housework.

The relationship between the division of housework and childbirth in the US has been studied by Torr and Short [39]. Households in which women do less housework are more likely to have second births, but this is also true for households with a more traditional division of housework. Further evidence that the division of housework matters for childbirths is presented by Cooke [40], who finds a positive relationship between the time spent by fathers in child care and the likelihood of second births in Germany. Men's involvement in child care here has a positive influence on birth rates. However, in the German case, men's relative time put into housework does not help to explaining second births.

In Sweden, where the welfare system in many respects is directed towards facilitating the combination of family and work life, the effect of housework might look different. In theory, combining family and work should not be that difficult in the Swedish context, where family policy measures help to ease women's responsibilities for child care. However, housework in Sweden is still highly gendered and beyond the scope of state intervention and so the relationship between unpaid housework and fertility needs more research. In this article, the sharing of daily chores, i.e. cooking, washing up, cleaning, laundry and grocery shopping, and its impact on family formation is explored. Couples in this study are split into three types, based on the division of housework and the distinguishing characteristics of the three couple types are examined. This is followed by the consideration of the central question: Does the division of housework, as a measurement of gender equality, have an impact on childbirths in Swedish families? This will be studied through analysing whether couples who organize their housework differently have a different probability of having their first or additional children over a period of eight years.

\section{DATA}

The data has been extracted from the yearly conducted Swedish Survey of Living Condition panel (ULF), which is a representative sample of the Swedish population between the ages of 16 and 84. This panel data started in 1979, and interviews for each panel are conducted every 8 years, with generally low levels of attrition. The objective of this article is to study how the division of housework influences if couples have their first or additional children. This requires household level information on the sharing of housework as well as household information on childbirth. The study was made possible by using the 1987 wave, the only year when the interviews included questions about the sharing of housework. Falling off and attrition between the waves 1987-1995 was $21.5 \%$, which is relatively low for a long-term longitudinal survey. A more detailed description of the data is found in Table 1. From a total of 1,972 individuals in the 1987 wave, cohabiting and married couples in which the woman was 40 years or younger in 1987 were selected for this study. The selection was based on the information on married and unmarried couples in the database. The second wave used in the study is 8 years later, 1995, when changes in the number of children are in focus. A problem which needed attention was the cases of interviewees who had separated from their partners and moved in with new partners who already had children. To avoid this problem, only individuals who were living together with the same partner in the 1995 wave were included, which left us with 470 individuals. The majority of the households in the study had children in 1987 (73\%). The proportion of households with children increased to $89 \%$ by 1995.

Table 1. Description of Data Material; Married and Cohabiting Couples, in Which the Women is Up to 40 Years Old in 1987 (Extraction from Swedish Survey of Living Condition Panel (ULF))

\begin{tabular}{|c|c|c|}
\hline Population & $\mathbf{1 9 8 7}$ & $\mathbf{1 9 9 5}$ \\
\hline \hline Couples still living together 1995 & & $\mathrm{n}=470$ \\
\hline Mean age of woman & $32 \mathrm{yrs}$ & +8 years \\
\hline Mean age of man & $35 \mathrm{yrs}$ & +8 years \\
\hline Proportion of households with children & $73 \%$ & $89 \%$ \\
\hline Mean number of children & 1,5 & 1,9 \\
\hline
\end{tabular}

\section{THE DEPENDENT VARIABLE}

The objective is to study whether the division of housework has an impact on childbirth. The dependent variable is a dichotomous variable indicating an increase in the Number of children between 1987 and 1995 and includes first births as well as subsequent births in the households during this period. In the ULF data, the variable "children" equals "living with children", which can be biological or adopted children.

\section{HOUSEWORK}

The main independent variable is how Housework is carried out within the household, i.e. how much of the housework the women or the men, respectively, are responsible for. In the ULF data, it is possible to identify the proportion of five different household tasks that are performed on a daily basis: cooking, washing up, cleaning, laundry and grocery shopping. The respondents were asked to assess to what 
extent they performed each task, with the alternatives: "I carry out a) all, or almost all of this task, b) approximately $3 / 4$, c) approximately $50 \%$, d) approximately $1 / 4$ or e) nothing or almost nothing". From these answers, an index was created, indicating how much of the housework was performed by the woman (in a factor analysis all variables loaded strongly into one dimension, with KMO of 0.80 , which supports the strategy of creating an index). The index spans from 5 to 25, where women in couples scoring 5 are responsible for all, or almost all, of the five household tasks. As many as $20 \%$ of the couples belonged to this group, and in most households the women were responsible for most of the housework. Most couples scored up to 9 on the index scale, which means that in most households, women were reported to perform the vast majority of domestic tasks.

Couples were subsequently split into three different types, based on the division of housework. The traditional group, in which women in large were responsible for the housework (up to 8 on the index scale), consisted of $38 \%$ of the households. In the intermediate group, comprising $40 \%$ of the respondents, women were still reported as responsible for most of the housework (with an index score between 9 and 13), although men were reportedly responsible for some housework tasks. In modern households, men did a substantial part of the housework, although not consistently a greater part (14 and over on the index scale). This last group made up $22 \%$ of the respondents. The households where the men carried out most of the housework were too few to be included separately in the study (in approximately $36 \%$ of the "modern" couples, men did most of the housework i.e. $8 \%$ of the total population). The various tasks displayed very differently gendered organisation, with laundry, cleaning and cooking as the most female-coded, while washing up and doing the groceries were more equally shared.

\section{OTHER INDEPENDENT VARIABLES}

In order to control the impact of housework on childbirth, other standard controls were included in the study: Employment, Socio-economic class, Total household income, Woman's proportion of household income, Number of children, Civil status and Woman's age. Previous studies, both Swedish and international, have highlighted the importance of labour market-variables for childbirth [41, 12]. In Sweden, where parental leave benefits are based on previous earnings, these might have even greater significance. Since women use the vast majority of the parental leave, even though parental leave is not reserved for mothers alone, women's employment status might be expected to have strong effects on childbirth. Employment was divided into four categories, the first two implying active participation on the labour market: full-time employment, which was by far more common amongst men (75\% vs. 34\% for women) and part-time employment, which was slightly more common than full-time employment amongst women (36\%), while only $3 \%$ of the men had part-time employment. The third category, leave of absence, included the men and women who had labour market attachment in 1987, although they are not active ( $14 \%$ for women and $4 \%$ for men). Here parental leave is included. The fourth category encompassed those outside the labour market, a variable which included, among others, students and the unemployed (16\% for women and $18 \%$ for men). In order to control for socioeconomic class, a scale close to the EGP classifications [42] was used, and simplified to distinguish between white and blue collar, placing higher and middle white collar and the self-employed in the white-collar category. $70 \%$ of the women and $54 \%$ of the men were classified as blue collar workers in 1987 . Household income can be expected to have an impact on child birth: couples with a higher income might be better able to afford children, yet it could also be argued that children of high-income couples "cost" more, which might have a negative effect on fertility [39, 43]. Household income is the total income of the household in 1987. The Woman's share of the household income i.e. her financial power, was also controlled for in the study.

Finally, demographic variables describing family composition were included in the analyses. Important variables such as the couple's Number of children at the first interview, Civil status, and the Woman's age were included. Since the two-child norm is strong in Sweden [44] and we can expect that families without children, or with one child, are more likely to have an additional child, the variable number of children was controlled for in the analyses. The number of children-variable was divided into three categories: no children, 1 child and 2 or more children. Civil status was also taken into account since decreased marriage rates are sometimes associated with lower fertility rates, yet the relatively long history of Swedish cohabitation might have been expected to contradict this pattern. A higher proportion of first births were found in cohabiting than in married couples in the early 2000s [45]. Lastly, women's age was included in the analysis: a significant factor since older women are generally less likely to have children. It is important to note that fertility has increased in the group of older women over recent decades [46], as has women's mean age at first birth. In Sweden, in 1987, the average age for a woman having her first child was 26, and this had risen by 1.5 years by the time of the second wave in the panel survey in 1995 [31]. In light of the small sample and the even smaller number of young women within the sample, women were divided into three age spans: 19-28 years, 29-33 years and 34-40 years.

\section{RESULTS - EXPLORING THE DIFFERENT COU- PLES}

Couples were split into three different types according to the division of housework. In traditional couples, women did the vast majority of the housework, while in modern couples, men made a substantial contribution to daily chores. In the intermediate group, women did most, but not all, of the housework. In Table 2 the characteristics of the three types of couples are described in order to explore the likelihood of other indicators that may support their labelling as "traditional", "intermediate" and "modern".

There is clearly sufficient evidence for distinguishing between traditional and modern couples. Women in modern couples are more frequently employed as compared to the women in the other couples: as many as $54 \%$ are full-time employed and $25 \%$ have part-time employment. Women in traditional couples are more frequently employed part-time and they are also more frequently represented amongst those outside the labour market. The difference in type of employment is not as pronounced amongst the men. In tradi- 
Table 2. Characteristics of Couples in the Study, Based on Three Categories of Couples According to How Housework is Shared (Swedish Survey of Living Condition Panel (ULF) Wave $1987+1995$ )

\begin{tabular}{|c|c|c|c|}
\hline & Traditional Couples $(\mathrm{n}=180)$ & Middle ( $n=186)$ & "Modern" Couples (n=104 \\
\hline \multicolumn{4}{|l|}{ Women's employment 1987} \\
\hline Full-time & $24 \%$ & $32 \%$ & $54 \%$ \\
\hline Part time & $38 \%$ & $40 \%$ & $25 \%$ \\
\hline \multicolumn{4}{|l|}{ Men's employment 1987} \\
\hline Full-time & $73 \%$ & $78 \%$ & $72 \%$ \\
\hline Part time & $1 \%$ & $4 \%$ & $5 \%$ \\
\hline \multicolumn{4}{|l|}{ Class 1987} \\
\hline Woman blue collar & $77 \%$ & $67 \%$ & $62 \%$ \\
\hline Man blue collar & $47 \%$ & $48 \%$ & $59 \%$ \\
\hline Total household income 1987 after taxation & 147.400 & 156.900 & 150.700 \\
\hline Woman's proportion of total household income 1987 & $36 \%$ & $38 \%$ & $44 \%$ \\
\hline \multicolumn{4}{|l|}{ Mean number of children } \\
\hline Proportion married 1987 & $90,6 \%$ & $86,6 \%$ & $75 \%$ \\
\hline \multicolumn{4}{|l|}{ Mean age 1987} \\
\hline $\operatorname{man}$ & $36 \mathrm{yrs}$ & $36 \mathrm{yrs}$ & $33 \mathrm{yrs}$ \\
\hline woman & $33 \mathrm{yrs}$ & $33 \mathrm{yrs}$ & $30 \mathrm{yrs}$ \\
\hline
\end{tabular}

tional couples, men are less frequently on leave of absence or part-time employed and they are consequently either employed full time or outside the labour market. Part-time work or leave of absence are, however, not common amongst any group of men. To view the class position of the couples, the proportion of blue-collar workers was calculated. This is admittedly a rough estimate, building on the socio-economic classification (SEI), yet it gives us valuable information on socio-economic differences. The proportion of women and men respectively classified as blue collar within the different couple types shows significant variations. The smallest difference within the group was found in modern couples, where $62 \%$ of the women and $59 \%$ of the men were classified as blue collar workers. Yet again, there is an obvious difference as compared to the traditional couples, where $77 \%$ of the women and only $47 \%$ of the men were classified as blue-collar workers.

With regard to income, the intermediate category displayed the highest total income of the three couple types in 1987, which can be explained by the fact that even if women were not as frequently employed full-time as in the modern couples, men in the intermediate group were more likely to be full-time employed and less likely to be outside the labour market. Traditional couples had the lowest income, and both women and men in this category were more frequently found outside the labour market. Women's proportion of the total household income was highest in modern couples at $44 \%$. 
Table 3. The Organization of Housework and Having Their First, or Additional Children (In-Between Interviews 1987-1995)

\begin{tabular}{|c|c|c|}
\hline & No Children & + Children \\
\hline \hline Traditional couples $(\mathrm{n}=180)$ & $59 \%(106)$ & $41 \%(74)$ \\
\hline Middle $(\mathrm{n}=186)$ & $60 \%(111)$ & $40 \%(75)$ \\
\hline Modern couples $(\mathrm{n}=104)$ & $38 \%(40)$ & $62 \%(64)$ \\
\hline
\end{tabular}

Pearson Chi-square significant at 0,001 level

Women in the two other categories had a similar proportion of the household income i.e. 36-38\%. With regard to labour market-related characteristics, there were noteworthy differences between the different couple types; women in modern couples stood out with a higher labour market attachment, a higher class position and a higher proportion of the household income.

The demographic variables also differed for the three couple types. The mean number of children for all couples in 1987 was 1.5 children. Modern couples had the fewest children: an average of 1 child in 1987 vs. 1.8 children in the traditional couples. Previous Swedish and international research on the division of housework should also be taken into consideration when exploring the link between housework and childbirth. Housework is more fairly shared in households without children, i.e. households that are more likely to be at the initial stage of family building [8]. In couples with children, women do more of the unpaid housework. Marriage is yet another divider between traditional and modern couples. A vast majority of the traditional couples in the 1987 wave were married: $90 \%$ vs. $87 \%$ in the intermediate group and $75 \%$ in the modern group. This could also be seen as an indication of more traditional values, as well as a question of age. Finally, there were age differences between the couples. In all couple types, men were on average three years older than their partners, but modern couples were as a group three years younger on average than the other couple types.

Summarizing the characteristics of the three couple types, we can see that traditional couples were more likely to be married and to display larger gendered class difference within the group; both men and women were more often found outside the labour market, which resulted in lower average income. The intermediate couples were found in the middle in most respects, except that these households had the highest average income. The modern group was younger than the other two groups, and women had a stronger attachment to the labour market, resulting in women's higher proportion of the total household income.

\section{RESULTS: HOUSEWORK AND CHILDBIRTH IN SWEDEN}

Having described the different types of couples, I will now turn to the relationship between housework and the birth of the couple's first or subsequent children in the period between panel interviews. Table 3 shows the proportion of couples in each category, and whether or not they had their first, or additional children. A majority of the modern couples had children in the period between the interviews: $62 \%$ as compared to $40 \%$ in the intermediate group and $41 \%$ in the traditional group.

Table 3 shows a significant correlation between the division of housework and having children at the 0.001 level. This indicates that more gender-equal couples are more likely to have their first, or additional children. The correlation between the gender-equal division of housework and of having children confirms previous research on this topic.

This relationship is further examined with the help of logistic regression models estimating the probability to have children in the period between panel interviews. In Table 4, three different logistic regression models are presented, in order to untangle the relationship between the different variables. As a base for comparison, Model 1 includes only the division of housework by means of the category variable "Women's share of housework". As previously mentioned, the division of housework is not assumed to be the only explanation to changes in the number of children. In Model 2, the regression is extended in order to explore how unpaid housework as well as paid work and socio-economic class, i.e. labour market -related variables, can contribute to the explanation. Finally, in Model 3, demographic characteristics of the household and its members are included.

In the first column, model 1 , the relationship between women's responsibility for housework and the probability of the couple's having (additional) children is in focus. The positive effect on childbearing of men's involvement in housework is clearly visible here. Translating the coefficient into over risks shows that these couples were almost $130 \%$ more likely than traditional couples to have their first or additional children.

Does the division of housework retain its significance when labour market attachment and socio-economic variables are taken into account? Model 2 includes women's share of the housework, and women's and men's time in paid employment, socio-economic class and the total household income as well as women's proportion of the household income. When including labour market variables in the regression model, the significance of sharing housework found in model 1 remains, and is even strengthened slightly. Couples where men did a substantial part of the housework were approximately $140 \%$ more likely to have children than traditional couples. The effect is significant and indicates that paid labour is not the only predictor of childbirth. The labour market variables show that women's labour market position is more important than men's as a predictor of having additional children. The results are, however, contradictory, since women working part-time were far less likely to have their first or additional children between the interviews, while 
Table 4. Logistic Regression Model Estimating Changes in Number of Children Between Interviews (1987-1995)

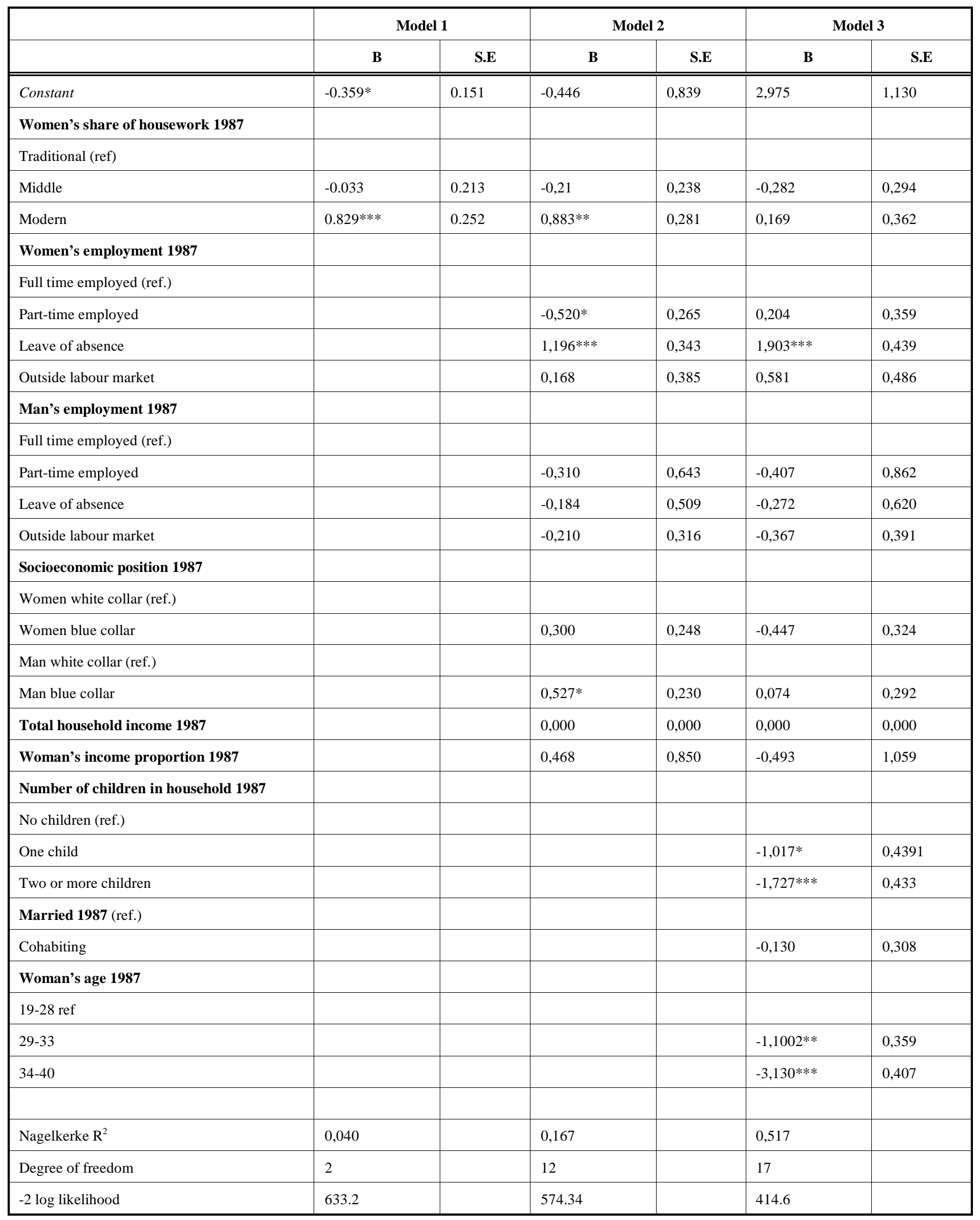

Levels of significance: $* * *=0.001-$ level $* *=0.01$-level $*=0.05$-level 
women on leave of absence were far more likely to have additional children. Translated into over and under risk, the gap between these two categories was even more apparent: part-time working women had an under risk of $68 \%$, whereas women on leave of absence had an over risk of $230 \%$. Within the Swedish context, part-time work is more common for mothers of younger children [20,35], which could imply that these women had already finished family formation and were thus less likely to have additional children. For the women on leave of absence, the likelihood of having children between the interviews was much higher than for women in full-time employment. This result is significant to a 0.001-level, and since parental leave was included in this variable, it could be assumed that women on parental leave have a higher probability of having their first, or additional children during the leave period. The argument that women's labour market situation has an impact on childbirth is strengthened by this analysis. Men's employment does not, on the other hand, alter the likelihood of the couple's s having their first or subsequent children. When considering the other variables, neither income nor women's socio-economic class has any significant effect. Blue collar men, however, were more likely to have children.

In the third model, demographic variables were added to the analysis, variables that proved to have great potential in explaining childbirths between the interviews. Firstly, childless couples were more likely to have children than couples who already had children. For couples with 2 , or more, children, the likelihood of having additional children between the interviews was lowest, with an under risk of over $400 \%$. Marital status did not have any significant impact on childbirths when first and additional births were studied together. The result would probably look different if only first, or only second births, were examined. This is because it is not unusual for Swedish couples to marry after the birth of their first child, making them more likely to have their first child as an unmarried, and their second as a married couple. Finally, the age variable had a significant effect on having children. Not surprisingly, older women were less likely to have children between the interviews.

A result from model 2 that remained significant, with increased effect, was women's leave of absence: women on leave were over $570 \%$ more likely to have children than women working full time. This does not, however, indicate that women's employment is unavoidably linked to plunging birth rates, since the women on leave had labour market attachment, although they were not participating actively in 1987.

How, then, does the division of housework affect childbirth? Once demographic variables were taken into account, the previously significant effect of more fairly shared housework disappeared. Two different aspects of the demographic variables, both connected with the division of housework, might help us interpret these findings. First, previous studies have shown that domestic tasks are more equally shared by childless couples. Secondly, the division of housework is reportedly fairer in younger couples. These two variables, childlessness and women's age, might interact in a way that accounts for the initial findings on the division of housework as a predictor of childbirth.

\section{CONCLUSION}

This article has examined the division of housework as a measurement of gender equality, the characteristics of Swedish couples and Swedish childbearing patterns. Sweden's relatively long history of high female labour market participation paired with generous parental leave and subsidized child care make it a useful test for the significance of gender relations within the family on childbirth.

First, couples were split into three different types, based on the division of housework. In modern couples, women had a stronger labour market attachment, a higher proportion of the household income and a higher class position, leading to the assumption that these couples could have different patterns of family formation. When exploring childbirth in the different couple types, the findings initially suggested that modern couples were likelier to have their first or additional children. Variables related to paid work were also shown to be important. Women's type of employment played a crucial role, with women on leave of absence far more likely to have children than women in part-time employment. While this might seem slightly ambiguous, the explanation could be that women on parental leave (here included in the 'leave of absence' category) were more likely to have additional children in the period between the interviews. Women who worked part-time, on the other hand, were likely to already have children of pre-school and/or school age and thus less likely to have additional children.

The different results for traditional, intermediate and modern couples must, however, be viewed against the background that the modern couples were younger, and had fewer children to begin with. When including demographic variables into the analysis, the effect of the fairer division of housework was no longer significant. Women's age and the number of children already in the family were more significant predictors of childbirth. The effect of leave of absence on childbirth was also significant when controlling for number of children in the household. While the evidence supports the argument that women's employment is an important predictor of childbirth, the panel data does not tell us anything about labour market variables in the period between the interviews.

As mentioned above, in connection with Table $\mathbf{2}$, the age difference between the different types of couples, and the number of children the couples had in 1987, are important in exploring the impact of housework on childbirth. Previous research on the division of housework has shown that even the more gender equal couples tend to fall back on traditional gender roles when they have children. In this study, many modern couples already had children in the first wave of 1987 , and the separate study of second births results could prove illuminating. The data material used here is too small to allow us to draw any general conclusions, yet the results for second births are similar to the findings of this article.

Despite differences in welfare systems and family policy the results in this study do not differ to a large extent from Torr and Short [39]'s findings for the U.S. This is somewhat 
surprising, since Sweden has a generous family policy scheme, and gender equality is high on the political agenda. However, Swedish family policy is directed towards child care, and even if the 'gender ideology' in Sweden promotes equal sharing of housework, the Swedish state does not intervene in the couples' domestic arrangements. At the time of the study there were no subsidies or benefits directed towards unpaid housework, except for childcare. This can also explain why Oláhs [47]' results give another picture since the gender equality measure she uses in her study is directed towards parental leave and fathers' time spent in childcare, which is an arena with high policy intervention in Sweden.

Even though the effect of the division of housework disappeared when demographic variables were included in the analyses, the initial findings on sharing housework and previous research on the significance of parental leave [47] emphasize the need for a more thorough examination of the role of gender relations within the family. Numerous researchers have argued that family forms and structure as well as family relations are undergoing significant changes. If families no longer have the same meaning, and the lives of both men and women are becoming more individualised, family formation pattern and childbearing patterns are likely to be affected.

\section{ACKNOWLEDGEMENTS}

The author would like to thank the Swedish Council for Working Life and Social Research for funding her work.

\section{REFERENCES}

[1] Daly M. Changing family life in Europe: Significance for state and society. Eur Soc 2005;7 (3): 379-98.

[2] Baxter J, Hewitt B, Western M. Post-familia families and the domestic division of labour. J Comp Fam Stud 2005; 36(4): 583-600.

[3] Lesthaeghe R, Neels K. From the first to the second demographic transition: an interpretation of the spatial continuity of demographic innovation in France, Belgium and Switzerland. Eur J Popul 2002; 18 (4): 325-60.

[4] Beck-Gernsheim E. Reinventing the Family - in search of new lifestyles. Cambridge: Polity press 2002.

[5] Giddens A. The Transformation of Intimacy: sexuality, love and eroticisms in modern societies. Cambridge: Polity Press 1993.

[6] Goldscheider F, Waite L. New families, no families? the transformation of the american home. Berkeley: University of California Press 1991.

[7] Klement C, Rudolph B. Employment patterns and economic independence of women in intimate relationships - A GermanFinnish comparison. Eur Soc 2004; 6 (3): 299-318.

[8] Nilsson K, Strandh M. The gendered organisation of paid work, housework and voluntary work in Sweden. In: Crespi I, Ed. Gender mainstreaming and family policy in Europe: perspective, researches and debates. Eum x: Macerata 2007; p. 199-224.

[9] Coltrane S. Research on household labor: modelling and measuring the social embeddedness of routine family work. J Marriage Fam 2000; 64(4):1280-33.

[10] McDonald P. Gender equity in theories of fertility transition. Popul Dev Rev 2000; 26(3): 427-39.

[11] Brewster KL, Rindfuss RR. Fertility and women's employment in industrialized nations. Annu Rev Sociol 2000; 26: 271-96.

[12] Hoem B. Utan jobb - inga barn? Fruktsamhetsutvecklingen på 1990-talet. SOU 2000: 37, Statens offentliga utredningar: Stockholm 2000.

[13] UNDP. Human Development Report. United Nations Development Programme: New York 2007.

[14] Strandh M. Nordenmark M. The interference of paid work with household demands in different social policy contexts: perceived work-household conflict in Sweden, the UK, the Netherlands, Hungary, and the Czech Republic. Br J Sociol 2006; 57: 597-617.

[15] Eurostat. Statistics. http://europa.eu.int. 2008.

[16] Löfström Å. Att lillan kom till jorden... Barnafödande och konjunktur under det sena 1900-talet, Umeå Economic Studies 603. Umeå University: Umeå 2003.

[17] OECD. Labour Force statistics 1981-2001. Part III. Paris 2001.

[18] Blossfeld H-P, Drobnic S. Careers of couples in contemporary society: from male breadwinner to dual-earner families. New York Oxford University Press 2001.

[19] Lewis J. Gender and welfare state change. Eur Soc 2002; 4(4):33157.

[20] Tijdens KG. Gender roles and labour use strategies: women's parttime work in the european union. Fem Econ 2002; 8:71-99.

[21] Drew E, Emerek R. Employment, Flexibility and gender. In: Drew E, Emerek R, Mahon E, Eds. Women, work and the family in Wurope, Routledge, London 1998; p. 89-98.

[22] Rindfuss RR, Guzzo KB, Morgan SP. The changing institutional context of low fertility. Popul Res Policy Rev 2003; 22: 411-38.

[23] Duvander A-Z, Olsson S. När har vi råd att skaffa barn. RFV analyserar 2000:8, Riksförsäkringsverket: Stockholm 2001.

[24] Försäkringskassan. The Swedish Social Insurance Agency. 2007. Available from: http//: www.forsakringskassan.se

[25] Vogel J. European Welfare regimes and the transition to adulthood: a comparative and longitudinal perspective. Soc Indic Res 2002; 59: 275-99.

[26] Brodmann S, Esping-Andersen G, Guell M. When fertility is bargained: second births in Denmark and Spain. Eur Sociol Rev 2007; 23 (5): 599-613.

[27] Chesnais J-C. Fertility, family and social policy in contemporary Western Europe. Popul Dev Rev1996; 22: 729-39.

[28] Statistics Sweden. Tid för vardagsliv. Living conditions report no 99, SCB, Örebro 2003

[29] Hochshild AR. (with A. Machung). The second shift. Viking: New York 1989.

[30] Breen R, Cooke LP. The persistence of the gendered division of domestic labour. Eur Sociol Rev 2005; 21: 43-57.

[31] Statistics Sweden. Hur många barn får jag när jag blir stor?. Demografiska rapporter 2002:5: SCB: Örebro 2002.

[32] Strandh M, Nordenmark N. Does family friendly policies influence the costs of being flexible?. In: Wallace C, Ed. HWF Survey comparative report. HWF report 6: Vienna 2003.

[33] Perrons D. Care, Paid work and leisure:rounding the triangle. Fem Econ 2000; 6: 105-14.

[34] Bittman M. Parenthood without penalty: time use and public policy in Australia and Finland. Fem Econ 1999; 5(3): 27-42.

[35] Gupta S. The Effects of transitions in marital status on men's performance of housework. J Marrige Fam 1999; 61: 700-11.

[36] Flood L, Gråsjö U. Tid för barn, tid för arbete - en undersökning av svenska hushålls tidsanvändning. In: Ahrne G, Persson I, Eds. Familj, makt och jämställdhet. SOU 1997:138: Statens offentliga utredningar: Stockholm 1997.

[37] South SJ, Spitze G. Housework in marital and non-marital Households. Am Sociol Rev 1994; 59 (3): 327-47.

[38] Kalleberg AL, Rosenfelt A. Work in the family and in the labour market: a cross-national, reciprocal analysis. J Marriage Fam 1990; 52: 331-46.

[39] Torr BM, Short SE. Second births and the second shift: a research note on gender equity and fertility. Popul Dev Rev 2004; 30 (1): 109-30.

[40] Cooke LP. The gendered division of labor and family outcomes in Germany. J Marriage Fam 2004; 66: 1246-59.

[41] Kalwij AS. The effects of female employment status on the presence and number of children. J Popul Econ 2000; 13 (2): 221-39.

[42] Eriksson R, Jonsson J. Can education be equalized? The Swedish case in comparative perspective. Oxford: Westview Press 1996.

[43] Robinson, WC. The economic theory of fertility over three decades. Pop Stud 1997; 51(1): 63-74.

[44] Bernhardt E. Familj och Karriär, Välfärdsbulletinen 4. Örebro 2000 . 
[45] Sleebos JE. Low Fertility rates in oecd countries: facts and policy responses. oecd social, employment and migration working papers no 15, OECD: Paris 2003.

[46] Rindfuss RR, Morgan SP, Offutt K. Education and the changing age pattern of American fertility: 1963-1989. Demography 1996; 33: 277-90.
[47] Oláh LSz. Gendering fertility: second births in Sweden and Hungary. Popul Res Policy Rev 2003; 22: 171-200.

Received: July 13, 2009

Revised: September 30, 2009

Accepted: October 15, 2009

(C) Karina Nilsson; Licensee Bentham Open.

This is an open access article licensed under the terms of the Creative Commons Attribution Non-Commercial License (http://creativecommons.org/licenses/by-nc/3.0/) which permits unrestricted, non-commercial use, distribution and reproduction in any medium, provided the work is properly cited. 